\title{
Genotypic Characterization of Non-0157 Shiga Toxin-Producing Escherichia coli in Beef Abattoirs of Argentina
}

\author{
M. O. MASANA, ${ }^{1 *}$ B. A. D’ASTEK, ${ }^{2}$ P. M. PALLADINO, ${ }^{1}$ L. GALli, $, 2,3$ L. L. DEL CASTILlO, ${ }^{1}$ C. CARBONARI, ${ }^{2}$ \\ G. A. LEOTTA, ${ }^{2,3}$ E. VILACOBA, ${ }^{2}$ K. IRINO, ${ }^{4}$ AND M. RIVAS ${ }^{2}$
}

\begin{abstract}
${ }^{1}$ Instituto Tecnología de Alimentos, Centro de Investigación de Agroindustria, Instituto Nacional de Tecnología Agropecuaria-INTA, CC. 77, B1708WAB Morón, Provincia de Buenos Aires, Argentina ; ${ }^{2}$ Servicio Fisiopatogenia, Instituto Nacional de Enfermedades Infecciosas-ANLIS 'Dr. Carlos G. Malbrán," Av. Vélez Sarsfield 563 (1281) Buenos Aires, Argentina; ${ }^{3}$ Consejo Nacional de Investigaciones Científicas y Técnicas-CONICET, Av. Rivadavia 1917 C1033AAJ, Buenos Aires, Argentina; and ${ }^{4}$ Seção de Bacteriologia, Instituto Adolfo Lutz, Av. Doutor Arnaldo 355, São Paulo 01246-902, Brazil
\end{abstract}

MS 11-189: Received 20 April 2011/Accepted 9 July 2011

\begin{abstract}
The non-O157 Shiga toxin-producing Escherichia coli (STEC) contamination in carcasses and feces of 811 bovines in nine beef abattoirs from Argentina was analyzed during a period of 17 months. The feces of 181 (22.3\%) bovines were positive for non-O157 STEC, while $73(9.0 \%)$ of the carcasses showed non-O157 STEC contamination. Non-O157 STEC strains isolated from feces (227) and carcasses (80) were characterized. The main serotypes identified were O178:H19, O8:H19, O130:H11, and O113:H21, all of which have produced sporadic cases of hemolytic-uremic syndrome in Argentina and worldwide. Twenty-two $(7.2 \%)$ strains carried a fully virulent stx/eae/ehxA genotype. Among them, strains of serotypes O103:[H2], O145:NM, and O111:NM represented $4.8 \%$ of the isolates. XbaI pulsed-field gel electrophoresis pattern analysis showed 234 different patterns, with 76 strains grouped in 30 clusters. Nine of the clusters grouped strains isolated from feces and from carcasses of the same or different bovines in a lot, while three clusters were comprised of strains distributed in more than one abattoir. Patterns AREXSX01.0157, AREXBX01.0015, and AREXPX01.0013 were identified as 100\% compatible with the patterns of one strain isolated from a hemolytic-uremic syndrome case and two strains previously isolated from beef medallions, included in the Argentine PulseNet Database. In this survey, 4.8\% (39 of 811) of the bovine carcasses appeared to be contaminated with nonO157 STEC strains potentially capable of producing sporadic human disease, and a lower proportion $(0.25 \%)$ with strains able to produce outbreaks of severe disease.
\end{abstract}

Shiga toxin-producing Escherichia coli (STEC) have been recognized as human pathogens since Karmali et al. (15) established their association with clinical cases of hemolytic-uremic syndrome (HUS). STEC O157:H7/NM (nonmotile) (STEC O157) is considered the prototype strain capable of producing severe foodborne disease outbreaks and, thus, is the focus of food legislation. Recently, the rising numbers of non-O157 STEC illnesses reported by health services worldwide have focused attention on the non-O157 STEC serotypes as a group of emerging pathogens of concern. Non-O157 STEC illness appears mostly as sporadic cases with mild to severe clinical symptoms, and yet, some non-O157 STEC serotypes have produced serious outbreaks. Usually, the relative importance of non-O157 STEC serotypes in human disease varies worldwide, with different serotypes being more prevalent in different countries (11).

In Argentina, HUS is endemic, with a high incidence of more than 500 cases per year. Postenteric HUS is considered the second-most-common cause of chronic kidney failure among children (31). According to the Argentine Database

\footnotetext{
* Author for correspondence. Tel: +54-11-4621-0457; Fax: +54-114621-2012; E-mail: mmasana@cnia.inta.gov.ar.
}

of the National Reference Laboratory for HUS surveillance, non-O157 STEC strains accounted for approximately $30 \%$ of STEC infections in the 2004 to 2009 period, with serogroups O145, O121, O26, O174, O111, and O103 being the most commonly associated with disease in order of frequency (28).

Reported sources of non-O157 STEC infection include foods such as sausages (4) and milk (5) and contaminated water (21), among others. However, in many cases, determination of the source of non-O157 STEC infection has been hindered by the lack of specific methodologies for their detection and isolation (3). Advances made by many research groups using immunomagnetic concentration and real-time PCR methods for specific serotypes have now begun to change this situation $(20,23)$.

The ability of non-O157 STEC serotypes to cause diarrhea, bloody diarrhea, or HUS varies considerably. However, more than 120 serotypes have been reported as human pathogens to date (20). The main determinants of non-O157 STEC virulence are coded in the Shiga toxin genes $\left(s t x_{1}\right.$ and $\left.s t x_{2}\right)$ and their variants and the eae gene, which is responsible for the production of the attaching and effacing lesions. Plasmid-carried genes, such as those encoding enterohemolysin $(e h x A)$, serine protease (espP), 
catalase-peroxidase (katP), and an autoagglutinating adhesin $(\mathrm{s} a \mathrm{a})$, have also been proposed as putative virulence factors in some non-O157 STEC strains. In 2003, Karmali et al. (13) proposed the classification of STEC into five seropathotypes (A to E) and correlated them to the distribution of pathogenic island O122. In this classification, non-O157 STEC strains of seropathotype B (O26:H11, O103:H2, O111:NM, O121:H19, and O145:NM) are the most hazardous, due to their association with HUS and ability to produce outbreaks, while the pathogenic potential of many non-O157 STEC serotypes of group E, isolated from bovines, is unknown. Thus, establishing the significance of non-O157 STEC in foods is a matter of concern and debate for sanitary authorities and the food industry $(7,20)$.

The aim of this study was to characterize the risk of non-O157 STEC in an important sector of the meat industry of Argentina. For that purpose, we conducted a survey for 17 months to detect non-O157 STEC in local abattoirs and genetically typed the non-O157 STEC strains isolated. The characteristics of STEC O157 strains recovered in abattoirs of Argentina have recently been published (19). The characterization of non-O157 STEC presented in this paper completes the survey report on STEC risk in local abattoirs.

\section{MATERIALS AND METHODS}

Sample collection and analysis. The descriptions of abattoir conditions and sample collection methods for this study are the same as those described in detail elsewhere (19). Briefly stated, 1,622 fecal and carcass samples from 811 bovines categorized as steers $(46 \%$ of the bovines, with an average carcass weight of $141 \mathrm{~kg})$, cows $(24 \%, 107 \mathrm{~kg})$, young steers $(17 \%, 109 \mathrm{~kg})$, heifers $(7 \%, 88 \mathrm{~kg})$, and calves $(6 \%, 73 \mathrm{~kg})$ were collected in nine beefexporting abattoirs of Argentina.

The fecal contents and carcass swabs of 6 consecutive bovines from lots of 30 to 60 animals were sampled per visit. Fecal samples were collected before complete evisceration by removing an amount of fecal mass from the descendent colon near the rectum using sterile stomacher bags. Carcass swabs were obtained, following a USDA methodology (33), with a sponge prewetted in $0.1 \%$ peptone water before entering the chilling rooms.

Stomacher bags containing fecal samples and sponges were placed into coolers with ice and sent to the laboratory to be processed within $18 \mathrm{~h}$.

Enrichment, isolation, and confirmation. All fecal samples (811) were analyzed for non-O157 STEC by direct swab onto MacConkey (MAC) agar plates (Difco, BD, Sparks, MD) and incubation at $37^{\circ} \mathrm{C}$ for $18 \mathrm{~h}$ (method A). All carcass swabs (811) and a fraction (251) of fecal samples were analyzed by an enrichment procedure (method $\mathrm{B}$ ).

In method B, $10 \mathrm{~g}$ of feces was incubated in $90 \mathrm{ml}$ of $\mathrm{GN}$ (gram-negative) Hajna broth (Difco, BD) at $37^{\circ} \mathrm{C}$ for $5 \mathrm{~h}$. For carcass sponges, incubation took place in $90 \mathrm{ml}$ of modified EC broth (Difco, BD) for $2 \mathrm{~h}$ at $37^{\circ} \mathrm{C}$. After the primary enrichment, $10-\mathrm{ml}$ amounts of the cultures were added to $90 \mathrm{ml}$ of MAC broth (Difco, BD) and further incubated at $37^{\circ} \mathrm{C}$ for $18 \mathrm{~h}$. One milliliter of MAC broth was centrifuged, and the pellet screened for stx genes by a modification of Meyer and Karch PCR (16). Each stxpositive pellet was plated onto MAC agar and, subsequently, in three consecutive eosin-methylene blue-Levine (Difco, BD) agar plates and incubated at $37^{\circ} \mathrm{C}$ for $18 \mathrm{~h}$.
Fecal and carcass samples were also processed by immunomagnetic separation with $\mathrm{O} 157$ immunomagnetic beads (Neogen Corporation, Lansing, MI), as described previously (19), and plated onto sorbitol MAC agar (Difco, BD) supplemented with cefixime-potassium tellurite (bioMérieux, Inc., Marcy l'Etoile, France) and onto O157:H7 ID agar (bioMérieux, Inc.) (method C).

The confluent growth zones from the MAC, cefiximepotassium tellurite-sorbitol MAC, and O157:H7 ID plates (methods A, B, and C) were screened for $s t x_{1}$, stx 2 , and $r f b_{\mathrm{O} 157}$ (O157 lipopolysaccharide) genes by multiplex PCR (17). At least 20 presumptive E. coli colonies were selected from any stxpositive $/ r f b_{\mathrm{O} 157}$-negative plates for PCR confirmation. Presumptive non-O157 STEC strains were isolated on Trypticase soy agar (Difco, BD), confirmed by multiplex PCR, and kept in Trypticase soy broth (Difco, BD) with $40 \%$ glycerol at $-70^{\circ} \mathrm{C}$ for further phenotypic and genotypic characterization.

Phenotypic and genotypic characterization of isolates. Confirmation of isolates as E. coli was performed through biochemical tests according to the method of Ewing (8). Serotyping was conducted according to the standard procedure of Ewing (8), using somatic (O1 to O181) and flagellar (H1 to H56) antisera prepared at the Adolfo Lutz Institute, São Paulo, Brazil, with strains obtained from the E. coli and Klebsiella International Reference Centre, Copenhagen, Denmark. The H types of some NM STEC strains were investigated for their H-type-specific (fliC) genes by restriction fragment length polymorphism analysis of the DNA fragments obtained by PCR as described by Machado et al. (18). Enterohemolysis was determined on sheep blood agar plates according to the method of Beutin et al. (2). Isolates were characterized by detection of the $s t x_{1}$ and $s t x_{2}$ genes by multiplex PCR as described above, while the eae and ehxA genes were investigated as described by Karch et al. (12) and Schmidt et al. (30), respectively.

To determine Stx production, bacterial supernatant fluids and periplasmic cell extracts were used in cytotoxicity assays on Vero cells according to the methodology of Karmali et al. (14).

Subtyping of isolates. The analysis of $s t x_{1}$ variants was conducted according to the method of Zhang et al. (34). Genotyping of $s t x_{2}$ variants was done by restriction fragment length polymorphism analysis of the B-subunit-encoding DNA fragments obtained by $\operatorname{PCR}(26,32)$.

Macro-restriction fragment analysis by pulsed-field gel electrophoresis (PFGE) was performed using the PulseNet 24-h standardized PFGE protocol for E. coli O157:H7 (27). Restriction digestion of DNA was carried out with the XbaI enzyme (Promega, Madison, WI). PFGE images of gels were obtained by using a Gel Doc 2000 (Bio-Rad, Milan, Italy). Analysis of TIFF images was carried out with the BioNumerics version 4.61 software package (Applied Maths, Sint-Martens-Latem, Belgium) using the Dice coefficient and the unweighted pair group method using average linkages to generate dendrograms with $1.5 \%$ tolerance values.

\section{RESULTS}

Prevalence of non-0157 STEC. From the 1,622 samples analyzed, 254 samples, 181 from feces and 73 from carcasses, were positive for the presence of non-O157 STEC, with rates of prevalence of 22.3 and 9.0\%, respectively. A total of 307 non-O157 STEC strains were isolated, 227 from feces and 80 from carcasses. More than one serotype was detected in $26(14.4 \%)$ of 181 fecal samples and in $5(6.8 \%)$ of 73 carcass samples (Table 1$)$. 
TABLE 1. Prevalence of non-O157 STEC in bovine feces and carcasses

\begin{tabular}{lccccc}
\hline Sample category & $\begin{array}{c}\text { No. of samples } \\
\text { analyzed }\end{array}$ & $\begin{array}{c}\text { No. (\%) of positive } \\
\text { samples }\end{array}$ & $95 \% \mathrm{Cl}^{a}$ & $\begin{array}{c}\text { No. of strains } \\
\text { isolated }\end{array}$ & $\begin{array}{c}\text { No. (\%) of samples with } \\
\text { more than one serotype }\end{array}$ \\
\hline Feces & 811 & $181(22.3)$ & $19.6-25.3$ & 227 & $26(14.4)$ \\
Carcass & 811 & $73(9.0)$ & $7.2-11.1$ & 80 & $5(6.8)$ \\
\hline
\end{tabular}

${ }^{a}$ 95\% CI, 95\% confidence interval.

All fecal samples (811) were analyzed by methods A and $\mathrm{C}$ and a fraction (251) by method $\mathrm{B}$, which was discontinued given the better results obtained by method A. The 811 carcass samples were analyzed by methods B and $\mathrm{C}$.

When an stx-positive confluent growth zone was detected by more than one method, the positive sample was attributed to methods $\mathrm{A}$ and $\mathrm{B}$ and/or $\mathrm{C}$ by which a non-O157 STEC strain was isolated and characterized.

Non-O157 STEC strains were detected in $140(17.3 \%)$ fecal samples by method A, with 169 strains isolated. By method B, $16(6.4 \%)$ fecal and $59(7.3 \%)$ carcass samples were positive, with 22 and 64 isolates, respectively (Table 2). By method C, 36 and 16 non-O157 STEC strains were isolated from $25(3.1 \%)$ fecal and $14(1.7 \%)$ carcass samples, respectively. Most positive carcass samples (59 of $73,81 \%$ ) and isolates (64 of $80,80 \%$ ) were detected by method B, while for feces, $77 \%$ (140 of 181) of the positive samples and $74 \%$ (169 of 227) of the isolates were detected by method A. Interestingly, 14\% (25 of 181) of the positive fecal samples and 19\% (14 of 73) of the positive carcass samples were found by nonspecific binding to STEC O157 immunomagnetic beads (method C).

Similar prevalence values of non-O157 STEC were observed in feces among the different bovine types, with higher frequencies in cull cows $(26.3 \%)$ and calves $(23.4 \%)$ (Table 3), while young steers $(16.2 \%)$ showed the highest rate of contamination in carcasses.

Figure 1 shows the numbers of analyzed and positive fecal samples during the study, comprising one winter, two summers, and one and a half autumn and spring seasons. The prevalence of non-O157 STEC in feces fluctuated from $17 \%$ in winter to $25 \%$ in summer, $22 \%$ in spring, and $23 \%$ in autumn. Higher frequencies of non-O157 STEC were found in heifers (29\%) and calves (57\%) in spring and in young steers $(33 \%)$ in summer. In contrast, higher frequencies were observed in steers $(30 \%)$ and cull cows $(33 \%)$ in autumn and winter, respectively.

On average, non-O157 STEC was detected in $9.0 \%$ of carcasses produced by the nine abattoirs under study; however, the contamination at each abattoir varied from 2.4 to $20 \%$. In all abattoirs, the number of contaminated carcasses was lower than the number of STEC carrier bovines, except in abattoir A (13 fecal versus 18 carcass samples).

Characterization of non-O157 STEC isolates. Three hundred seven non-O157 STEC isolates were characterized by phenotype, serotype, genotype, and XbaI-PFGE analysis. The results for characterization by serotype and genotype are presented for 293 strains, as isolates from the same sample with identical serotypes, genotypes, and $\mathrm{X} b a \mathrm{I}$-PFGE patterns were considered duplicates and removed from the database. In addition, 13 isolates were further excluded from the XbaI-PFGE analysis because of bacterial lyses.

Phenotypic characterization. The majority of nonO157 STEC strains were sorbitol fermenting (96\%) and $\beta$ D-glucuronidase (90\%) and enterohemolysin (64\%) positive. In Vero cell cultures, Stx 2 production was predominant (63\%), followed by the Stx $1 /$ Stx 2 combination (28\%) and Stx 1 only (9\%).

Serotyping. Among the 293 non-O157 STEC isolates, 194 belonged to $27 \mathrm{O}$ groups (O2, O7, O8, O15, O22, O39, O46, O73, O74, O79, O82, O91, O103, O111, O113, O116, O130, O136, O139, O141, O145, O153, O163, O165, O174, O178, and O179), while 99 isolates were nontypeable (ONT). Eighteen H antigens (H2, H7, H8, H11, H12, H14, H16, H18, H19, H21, H25, H27, H28, H38, H42, $\mathrm{H} 45, \mathrm{H} 46$, and H49) were determined in 258 strains, while

TABLE 2. Recovery of non-O157 STEC from fecal and carcass samples by different methods

\begin{tabular}{|c|c|c|c|c|}
\hline \multirow[b]{3}{*}{ Method } & \multicolumn{4}{|c|}{ Recovery from: } \\
\hline & \multicolumn{2}{|c|}{ Fecal samples } & \multicolumn{2}{|c|}{ Carcass samples } \\
\hline & No. positive/no. tested (\%) & No. of isolates & No. positive/no. tested (\%) & No. of isolates \\
\hline $\mathrm{A}^{a}$ & $140 / 811(17.3)$ & 169 & $\mathrm{ND}^{b}$ & ND \\
\hline $\mathrm{B}^{c}$ & $16 / 251(6.4)$ & 22 & $59 / 811(7.3)$ & 64 \\
\hline $\mathrm{C}^{d}$ & $25 / 811(3.1)$ & 36 & 14/811 (1.7) & 16 \\
\hline Total & $181 / 811(22.3)$ & 227 & $73 / 811(9.0)$ & 80 \\
\hline
\end{tabular}

\footnotetext{
${ }^{a}$ Direct swab.

${ }^{b} \mathrm{ND}$, not done.

${ }^{c}$ Broth enrichment.

${ }^{d}$ O157 immunomagnetic separation.
} 
TABLE 3. Prevalence of non-O157 STEC in feces and carcasses according to bovine classification

\begin{tabular}{llcc}
\hline $\begin{array}{c}\text { Bovine } \\
\text { classification }\end{array}$ & Sample category & No. of samples & $\begin{array}{c}\text { No. (\%) of } \\
\text { positive samples }\end{array}$ \\
\hline Steer & Feces & 373 & $80(21.4)$ \\
Cull cow & Carcass & 373 & $27(7.2)$ \\
& Feces & 198 & $52(26.3)$ \\
Young steer & Carcass & 198 & $16(8.1)$ \\
& Feces & 136 & $27(19.9)$ \\
Heifer & Carcass & 136 & $22(16.2)$ \\
& Feces & 57 & $11(19.3)$ \\
Calf & Carcass & 57 & $6(10.5)$ \\
& Feces & 47 & $11(23.4)$ \\
& Carcass & 47 & $2(4.3)$ \\
\hline
\end{tabular}

33 strains were NM, and two were rough (HR). The nonO157 STEC strains were grouped into 35 different serotypes, of which 4, O178:H19 $(n=32)$, O8:H19 $(n=$ 28), O130:H11 ( $n=22)$, and O113:H21 $(n=17)$, were the most prevalent, representing 34\% of the isolates (Table 4). Among the nontypeable somatic strains, ONT:H2 $(n=32)$ and ONT:H7 ( $n=19)$ were the most prevalent.

Thirty-three serotypes were identified in fecal samples, predominant among which were O178:H19 $(n=22)$, O8:H19 $(n=18)$, and O130:H11 $(n=16)$. On the other hand, 78 strains isolated from carcasses were grouped into 18 different serotypes (Table 4), the most frequently isolated being O8:H19 ( $n=10)$ O178:H19 ( $n=10)$, O130:H11 $(n=6)$, and O113:H21 $(n=5)$.
Genotypic characterization. The following variants of the Shiga toxin gene were present in the non-O157 STEC isolates: $s t x_{2}(28.3 \%)$, stx $1 /$ stx $_{2}(17.6 \%)$, st $x_{2 \mathrm{c}(\mathrm{vh}-\mathrm{b})}(17.6 \%)$, $\operatorname{stx}_{1}(9.4 \%), \operatorname{stx}_{2 \mathrm{c}(\mathrm{vh}-\mathrm{a})}(7.2 \%)$, stx $_{1} / \mathrm{stx}_{2 \mathrm{c}(\mathrm{vh}-\mathrm{b})}(5.2 \%)$, stx $_{1} /$

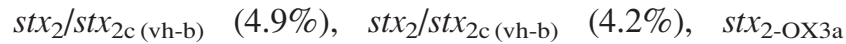
$(2.0 \%), s_{2}$ NT $(1.6 \%), s_{2} / x_{2 t} x_{2 \mathrm{c}(\mathrm{vh}-\mathrm{a})}(1.3 \%)$, and $s t x_{2 \mathrm{c}(\mathrm{vh}-\mathrm{a})} /$ $s t x_{2 \mathrm{c}(\mathrm{vh}-\mathrm{b})}(0.7 \%)$. Other virulence factors, such as the eae (7.2\%), ehxA (66.4\%), and saa (49.5\%) genes, were also determined in the strains.

Twenty-six different virulence genotypes were established, given the combinations of virulence factors. The most prevalent genotype was $s t x_{1} /$ st $x_{2} /$ eh $x A /$ saa (49 strains), followed by $s t x_{2 \mathrm{c}(\mathrm{vh}-\mathrm{b})}$ (45 strains) and $s t x_{2} / \mathrm{eh} x A /$ saa (41 strains) (Table 5). Twenty-two strains $(7.5 \%)$, belonging to the O103:[H2] $(n=10), \mathrm{O} 145: \mathrm{NM}(n=3), \mathrm{O} 111: \mathrm{NM}(n$ $=1), \mathrm{O} 165: \mathrm{NM}(n=1), \mathrm{O} 139: \mathrm{H} 25(n=1), \mathrm{ONT}: \mathrm{H} 7(n$ $=1)$, ONT:H19 $(n=1)$, ONT:H28 $(n=1)$, and ONT:NM $(n=3)$ serotypes, carried the eae and $e h x A$ genes.

PFGE characterization of non-0157 STEC strains. The clonal relatedness of 280 non-O157 STEC strains was established by PFGE of genomic DNA after digestion with XbaI. PFGE analysis showed 234 different patterns with $62 \%$ similarity, with 76 strains grouped in 30 clusters (I to XXX) of 2 to 4 strains each and 100\% homology (Table 6). Unique patterns were observed for 204 strains.

Isolates that grouped in clusters showed different associations. Nine clusters (I, VIII, X, XVII, XIX, XXI, $\mathrm{XXII}, \mathrm{XXV}$, and $\mathrm{XXX)}$ grouped strains isolated only from feces of different bovines of the same lot. Eight clusters (III,

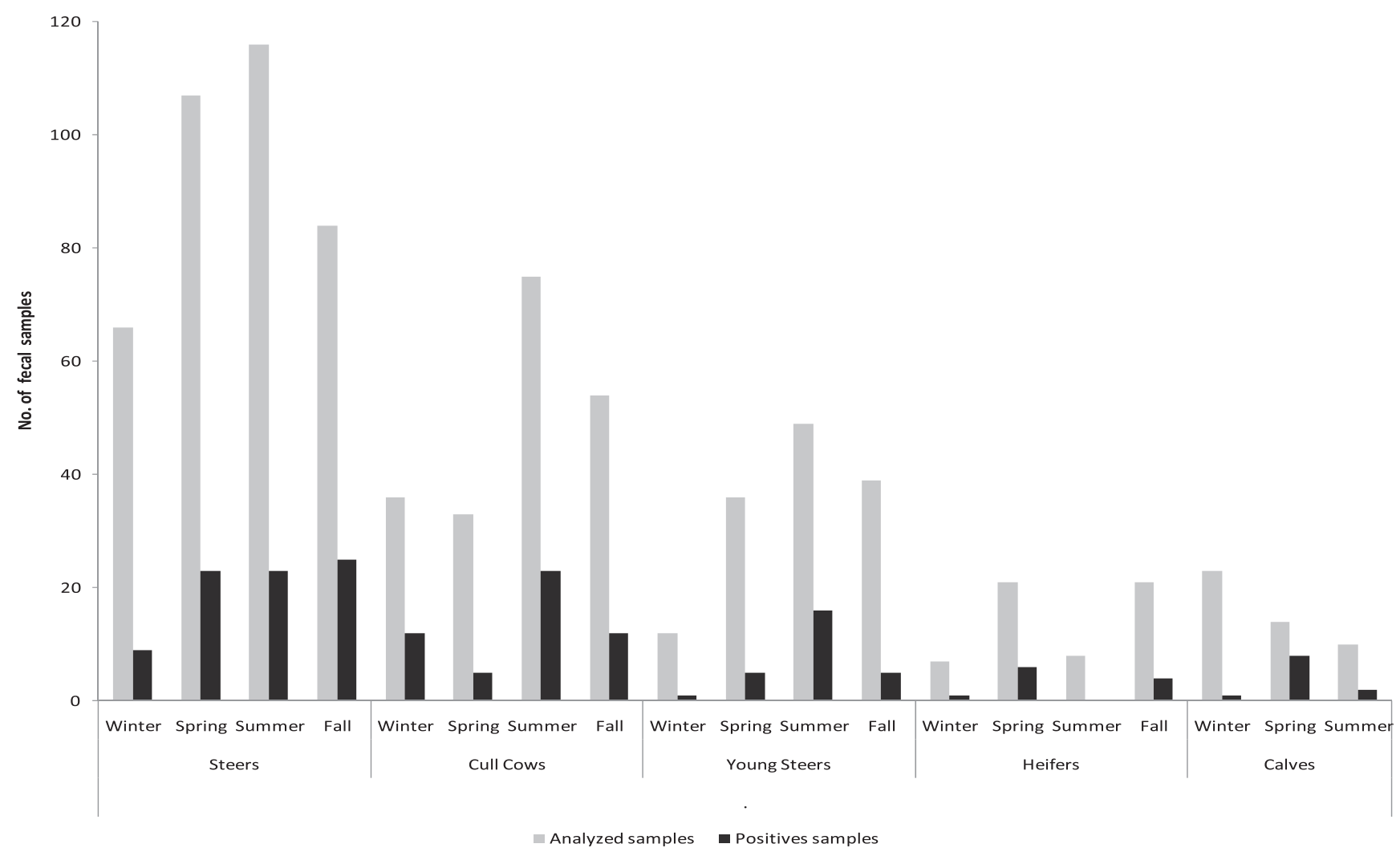

FIGURE 1. Distribution of non-O157 STEC-positive fecal samples per season and bovine type. 
TABLE 4. Serotypes of non-O157 STEC strains isolated from bovine feces and carcasses

\begin{tabular}{|c|c|c|c|}
\hline \multirow[b]{2}{*}{ Serotype $^{a}$} & \multicolumn{2}{|c|}{ No. of isolates from: } & \multirow{2}{*}{$\begin{array}{c}\text { Total no. (\% } \\
\text { of isolates }\end{array}$} \\
\hline & Feces & Carcasses & \\
\hline O178:H19 & 22 & 10 & $32(10.9)$ \\
\hline O8:H19 & 18 & 10 & $28(9.6)$ \\
\hline$\overline{\text { O130:H11 }}$ & 16 & 6 & $22(7.5)$ \\
\hline$\overline{\mathrm{O} 113: \mathrm{H} 21}$ & 12 & 5 & $17(5.8)$ \\
\hline 0174:H21 & 7 & 4 & $11(3.8)$ \\
\hline$\overline{0103:[\mathrm{H} 2]}$ & 9 & 1 & $10(3.4)$ \\
\hline $\mathrm{O} 7: \mathrm{H} 21$ & 6 & 1 & 7 (2.4) \\
\hline O39:H49 & 5 & 2 & $7(2.4)$ \\
\hline O91:H21 & 5 & 2 & $7(2.4)$ \\
\hline$\overline{\mathrm{O82}: \mathrm{H8}}$ & 3 & 2 & $5(1.7)$ \\
\hline O141:H49 & 1 & 4 & $5(1.7)$ \\
\hline O22:H16 & 3 & & $3(1.0)$ \\
\hline 0145:NM & 3 & & $3(1.0)$ \\
\hline$\overline{\mathrm{O} 22: \mathrm{H8}}$ & 2 & 1 & $3(1.0)$ \\
\hline O8:H16 & 1 & 2 & $3(1.0)$ \\
\hline$\overline{\text { O79:H19 }}$ & 1 & 2 & $3(1.0)$ \\
\hline O179:H8 & 1 & 2 & $3(1.0)$ \\
\hline O46:H38 & 2 & & $2(0.7)$ \\
\hline O74:H42 & 2 & & $2(0.7)$ \\
\hline O136:H12 & 2 & & $2(0.7)$ \\
\hline O74:HR & 1 & 1 & $2(0.7)$ \\
\hline O153:H25 & 1 & 1 & $2(0.7)$ \\
\hline O103:NM & & 2 & $2(0.7)$ \\
\hline $\mathrm{O} 2: \mathrm{H} 45$ & 1 & & $1(0.3)$ \\
\hline O8:H7 & 1 & & $1(0.3)$ \\
\hline O15:H27 & 1 & & $1(0.3)$ \\
\hline O39:NM & 1 & & $1(0.3)$ \\
\hline O73:H18 & 1 & & $1(0.3)$ \\
\hline O74:H28 & 1 & & $1(0.3)$ \\
\hline O91:H16 & 1 & & $1(0.3)$ \\
\hline 0111:NM & 1 & & $1(0.3)$ \\
\hline$\overline{\mathrm{O} 139: \mathrm{H} 25}$ & 1 & & $1(0.3)$ \\
\hline O153:NM & 1 & & $1(0.3)$ \\
\hline O163:H19 & 1 & & $1(0.3)$ \\
\hline O165:NM & 1 & & $1(0.3)$ \\
\hline O116:H21 & & 1 & $1(0.3)$ \\
\hline ONT:H2 & 25 & 7 & $32(10.9)$ \\
\hline ONT:H7 & 17 & 2 & $19(6.5)$ \\
\hline ONT:NM & 13 & 1 & $14(4.8)$ \\
\hline ONT:H21 & 10 & 1 & $11(3.8)$ \\
\hline ONT:H46 & 6 & 3 & $9(3.1)$ \\
\hline ONT:H19 & 3 & 1 & $4(1.4)$ \\
\hline ONT:H28 & 3 & 1 & $4(1.4)$ \\
\hline ONT:H16 & 2 & & $2(0.7)$ \\
\hline ONT:H8 & 1 & 1 & $2(0.7)$ \\
\hline ONT:H14 & & 1 & $1(0.3)$ \\
\hline ONT:H25 & & 1 & $1(0.3)$ \\
\hline
\end{tabular}

${ }^{a}$ Serotypes reported as human pathogens worldwide are shown in boldface, and serotypes reported as human pathogens in Argentina are underlined.

VI, VII, XV, XVIII, XX, XXVII, and XXIX) only gathered strains from different carcasses of a lot.

In some clusters, the association of strains from feces and carcasses in one lot was shown, in five cases from the same animal (V, XIV, XVI, XXIV, and XXVIII) and in four instances from different animals (II, IX, XI, and XII).
TABLE 5. Genotypes of non-O157 STEC strains isolated from bovine feces and carcasses

\begin{tabular}{|c|c|c|c|}
\hline \multirow[b]{2}{*}{ Genotype } & \multicolumn{2}{|c|}{ No. of isolates from: } & \multirow{2}{*}{$\begin{array}{c}\text { Total no. (\%) } \\
\text { of isolates }\end{array}$} \\
\hline & Feces & Carcasses & \\
\hline stx $x_{1} /$ stx $2 / e h x A / s a a$ & 32 & 17 & $49(16.7)$ \\
\hline stx $_{2 \mathrm{c}(\mathrm{vh}-\mathrm{b})}$ & 35 & 10 & $45(15.4)$ \\
\hline stx $x_{2} / e h x A / s a a$ & 30 & 11 & $41(14.0)$ \\
\hline$s t x_{2} / e h x A$ & 16 & 8 & $24(8.2)$ \\
\hline$s t x_{2 \mathrm{c}(\mathrm{vh}-\mathrm{a})}$ & 19 & 3 & $22(7.5)$ \\
\hline$s t x_{1} / s t x_{2 \mathrm{c}(\mathrm{vh}-\mathrm{b})} / e h x A / s a a$ & 10 & 3 & $13(4.4)$ \\
\hline $\operatorname{stx}_{2} /$ stx $_{2 \mathrm{c}(\mathrm{vh}-\mathrm{b})} / \mathrm{eh} x \mathrm{~A} / \mathrm{saa}$ & 9 & 4 & $13(4.4)$ \\
\hline stx $x_{1} / e a e / e h x A$ & 11 & 1 & $12(4.1)$ \\
\hline stx $x_{1}$ & 9 & 2 & $11(3.8)$ \\
\hline $\operatorname{stx}_{1} /$ stx $_{2} /$ stx $_{2 \mathrm{c}(\mathrm{vh}-\mathrm{b})} / \operatorname{eh} x A / \mathrm{saa}$ & 8 & 4 & $12(4.1)$ \\
\hline stx $x_{2}$ & 8 & 1 & $9(3.1)$ \\
\hline stx $x_{2} /$ eaeleh $x A$ & 6 & 1 & $7(2.4)$ \\
\hline$s_{2} x_{2 \mathrm{c}(\mathrm{vh}-\mathrm{b})} / \mathrm{eh} x A / \mathrm{saa}$ & 3 & 4 & $7(2.4)$ \\
\hline stx 2 -OX3a & 5 & & $5(1.7)$ \\
\hline $\operatorname{stx}_{1} / e h x A / s a a$ & 2 & 2 & $4(1.4)$ \\
\hline stx $x_{2} \mathrm{NT}$ & 1 & 3 & $4(1.4)$ \\
\hline stx $1 / s t x_{2 \mathrm{c}(\mathrm{vh}-\mathrm{b})}$ & 1 & 1 & $2(0.7)$ \\
\hline $\operatorname{stx}_{1} /$ stx $_{2 \mathrm{c}(\mathrm{vh}-\mathrm{a})}$ & 1 & 1 & $2(0.7)$ \\
\hline$s t x_{2 \mathrm{c}(\mathrm{vh}-\mathrm{a})} / s t x_{2 \mathrm{c}(\mathrm{vh}-\mathrm{b})}$ & 2 & & $2(0.7)$ \\
\hline stx $_{2} /$ stx $_{2 \mathrm{c}(\mathrm{vh}-\mathrm{a})} /$ eae/eh $x A$ & 2 & & $2(0.7)$ \\
\hline stx $x_{1} / e h x A$ & 2 & & $2(0.7)$ \\
\hline stx $_{2 \mathrm{c}(\mathrm{vh}-\mathrm{b})} /$ eaeleh $x A$ & 1 & & $1(0.3)$ \\
\hline stx $x_{1} /$ stx 2 NT/ehxA/saa & 1 & & $1(0.3)$ \\
\hline stx $x_{2-\mathrm{O} 3 \mathrm{a}} / e h x A$ & 1 & & $1(0.3)$ \\
\hline stx $_{2} \mathrm{NT} / e h x A / s a a$ & & 1 & $1(0.3)$ \\
\hline stx $1 /$ stx $x_{2} / e h x A$ & & 1 & $1(0.3)$ \\
\hline
\end{tabular}

Cluster V also included a strain isolated from a carcass in another visit to abattoir $\mathrm{C}$, and cluster IX one strain recovered from a carcass in a different abattoir.

Finally, clusters XIII, XXIII, and XXVI grouped strains from more than one abattoir, two abattoirs in clusters XXIII and XXVI and three abattoirs in cluster XIII, while cluster IV grouped isolates from different visits to abattoir C.

The 32 STEC strains of serotype O178:H19 (Fig. 2) have a $73.2 \%$ similarity with two main branches associated with their genotype. Five clusters (XII, XIII, XV, XVI, and $\mathrm{XXV}$ ) are composed of 12 strains of this serotype with the AREXSX01.0157 pattern included in the PulseNet Database of Argentina, as previously found in an HUS case.

Among the predominant serotypes, the AREXBX01.0015 pattern (cluster XXIV) detected in STEC O8:H19 strains has previously been identified in one strain isolated from a beef product, and the AREXPX01.0013 pattern (cluster IX) has previously been identified in STEC O113:H21 strains recovered from beef samples.

\section{DISCUSSION}

The non-O157 STEC contamination in beef cattle processing plants of Argentina was studied during a 17month period. The supply of cattle to the abattoirs was mostly $(88 \%)$ obtained from the main cattle-rearing regions of Argentina: Buenos Aires, Santa Fé, Entre Ríos, Córdoba, and La Pampa provinces. The majority of the nine 
TABLE 6. Distribution of non-O157 STEC strains in Xbal-PFGE clusters

\begin{tabular}{|c|c|c|c|c|c|c|c|}
\hline Cluster & XbaI-PFGE pattern & Serotype & Genotype & Abattoir & Visit & Sample type ${ }^{a}$ & No. of isolates \\
\hline I & AREXWX01.0012 & O103:[H2] & stx $x_{1} /$ eae/eh $x A$ & $\mathrm{D}$ & 11 & $\mathrm{~F}$ & 4 \\
\hline \multirow[t]{2}{*}{ II } & AREXWX01.0004 & O103:[H2] & st $x_{1} /$ eaelehxA & A & 1 & $\mathrm{C}$ & 1 \\
\hline & & & & & & $\mathrm{F}$ & 1 \\
\hline III & AREHBX01.0011 & O130:H11 & st $x_{1} / e h x A / s a a$ & $\mathrm{D}$ & 2 & $\mathrm{C}$ & 2 \\
\hline \multirow{2}{*}{ IV } & AREHBX01.0013 & O130:H11 & stx $x_{1} / s t x_{2 \mathrm{c}(\mathrm{vh}-\mathrm{b})} / e h x A /$ saa & $\mathrm{C}$ & 8 & $\mathrm{~F}$ & 1 \\
\hline & & & & & 15 & $\mathrm{~F}$ & 2 \\
\hline \multirow[t]{3}{*}{ V } & AREHBX01.0003 & O130:H11 & st $x_{1} /$ st $x_{2} /$ ehxA/saa & $\mathrm{C}$ & 3 & $\mathrm{C}$ & 1 \\
\hline & & & stx $_{1} /$ stx $_{2} /$ stx $x_{2 \mathrm{c}(\mathrm{vh}-\mathrm{b})} / \operatorname{eh} x A / \operatorname{saa}$ & $\mathrm{C}$ & 7 & $\mathrm{~F}$ & 1 \\
\hline & & & stx $_{1} /$ stx $_{2} /$ stx $x_{2 \mathrm{c}(\mathrm{vh}-\mathrm{b})} / e h x A /$ saa & $\mathrm{C}$ & 7 & $\mathrm{C}$ & 1 \\
\hline VI & AREXSX01.0225 & O82:H8 & $s_{2} x_{2 \mathrm{c}(\mathrm{vh}-\mathrm{b})} / \mathrm{eh} x A / \mathrm{saa}$ & A & 3 & $\mathrm{C}$ & 2 \\
\hline VII & AREXSX01.0246 & ONT:H2 & st $x_{2} \mathrm{NT}$ & $\mathrm{G}$ & 3 & $\mathrm{C}$ & 2 \\
\hline VIII & AREXPX01.0028 & O113:H21 & stx $_{1} /$ stx $_{2} /$ stx $_{2 \mathrm{c}(\mathrm{vh}-\mathrm{b})} / \operatorname{eh} x A / \operatorname{saa}$ & G & 3 & $\mathrm{~F}$ & 2 \\
\hline \multirow[t]{3}{*}{ IX } & AREXPX01.0013 & $\mathrm{O} 113: \mathrm{H} 21$ & stx $x_{2} / e h x A / s a a$ & $\mathrm{C}$ & 8 & $\mathrm{C}$ & 1 \\
\hline & & & & & & $\mathrm{F}$ & 1 \\
\hline & & & & G & 10 & $\mathrm{C}$ & 1 \\
\hline$X$ & AREXSX01.0185 & ONT:H46 & stx $x_{2} / e h x A / s a a$ & $\mathrm{D}$ & 2 & $\mathrm{~F}$ & 4 \\
\hline \multirow[t]{2}{*}{ XI } & AREZDX01.0020 & $\mathrm{O} 174: \mathrm{H} 21$ & $s t x_{2 \mathrm{c}(\mathrm{vh}-\mathrm{b})}$ & A & 3 & $\mathrm{C}$ & 1 \\
\hline & & & & & & $\mathrm{F}$ & 3 \\
\hline \multirow[t]{3}{*}{ XII } & AREXSX01.0320 & O178:H19 & stx $2 \mathrm{NT}$ & G & 5 & $\mathrm{C}$ & 1 \\
\hline & & & $s_{2} x_{2 \mathrm{c}(\mathrm{vh}-\mathrm{a})}$ & G & 5 & $\mathrm{C}$ & 1 \\
\hline & & & & & & $\mathrm{F}$ & 1 \\
\hline \multirow[t]{3}{*}{ XIII } & AREXSX01.0323 & O178:H19 & stx $x_{2} /$ stx $2 \mathrm{c}$ (vh-a) & B & 5 & $\mathrm{C}$ & 1 \\
\hline & & & $s t x_{2 \mathrm{c}(\mathrm{vh}-\mathrm{a})}$ & A & 1 & $\mathrm{~F}$ & 1 \\
\hline & & & & G & 1 & $\mathrm{~F}$ & 1 \\
\hline \multirow[t]{2}{*}{ XIV } & AREKKX01.0016 & O91:H21 & stx $x_{2} / e h x A / s a a$ & $\mathrm{E}$ & 2 & $\mathrm{C}$ & 1 \\
\hline & & & & & & $\mathrm{F}$ & 1 \\
\hline $\mathrm{XV}$ & AREXSX01.0329 & O178:H19 & stx $x_{1} /$ stx $2 /$ ehxA $/$ saa & $\mathrm{D}$ & 2 & $\mathrm{C}$ & 3 \\
\hline \multirow[t]{2}{*}{ XVI } & AREXSX01.0333 & O178:H19 & stx $1 /$ stx $x_{2} / e h x A / s a a$ & B & 4 & $\mathrm{C}$ & 1 \\
\hline & & & & & & $\mathrm{F}$ & 1 \\
\hline XVII & AREXBX01.0043 & O8:H19 & stx $x_{2} / e h x A$ & $\mathrm{D}$ & 10 & $\mathrm{~F}$ & 2 \\
\hline XVIII & AREXBX01.0044 & O8:H19 & $s t x_{2} / \operatorname{eh} x A$ & $\mathrm{H}$ & 7 & $\mathrm{C}$ & 3 \\
\hline XIX & AREXSX01.0167 & O46:H38 & stx $x_{1} /$ stx $x_{2} /$ ehxA/saa & G & 4 & $\mathrm{~F}$ & 2 \\
\hline $\mathrm{XX}$ & AREXSX01.0046 & ONT:H2 & $\operatorname{stx}_{2 \mathrm{c}(\mathrm{vh}-\mathrm{b})}$ & A & 10 & $\mathrm{C}$ & 2 \\
\hline XXI & AREXSX01.0247 & ONT:H2 & $s x_{2 \mathrm{c}(\mathrm{vh}-\mathrm{a})}$ & G & 3 & $\mathrm{~F}$ & 2 \\
\hline XXII & ARENMX01.0084 & O145:NM & st $x_{2} /$ eaeleh $x A$ & $\mathrm{D}$ & 10 & $\mathrm{~F}$ & 2 \\
\hline \multirow[t]{2}{*}{ XXIII } & AREXBX01.0034 & O8:H19 & stx $x_{1} / \operatorname{st} x_{2} / e h x A$ & $\mathrm{D}$ & 5 & $\mathrm{C}$ & 1 \\
\hline & & & stx $x_{1} /$ stx $x_{2} \mathrm{NT} / e h x A /$ saa & $\mathrm{F}$ & 13 & $\mathrm{~F}$ & 1 \\
\hline \multirow[t]{2}{*}{ XXIV } & AREXBX01.0015 & O8:H19 & stx $x_{1} /$ stx $x_{2} / e h x A / s a a$ & $\mathrm{~F}$ & 3 & $\mathrm{C}$ & 1 \\
\hline & & & & & & $\mathrm{F}$ & 2 \\
\hline XXV & AREXSX01.0347 & O178:H19 & $s t x_{2 \mathrm{c}(\mathrm{vh}-\mathrm{b})}$ & $\mathrm{C}$ & 6 & $\mathrm{~F}$ & 2 \\
\hline \multirow[t]{2}{*}{ XXVI } & AREXSX01.0161 & ONT:H7 & $s t x_{2 \mathrm{c}(\mathrm{vh}-\mathrm{b})}$ & A & 3 & $\mathrm{C}$ & 1 \\
\hline & & & & B & 2 & $\mathrm{~F}$ & 1 \\
\hline XXVII & AREXSX01.0133 & O141:H49 & stx $x_{1} /$ stx $x_{2} /$ ehxA/saa & A & 12 & $\mathrm{C}$ & 4 \\
\hline \multirow[t]{2}{*}{ XXVIII } & AREXBX01.0030 & O8:H16 & stx $x_{1} /$ stx $x_{2} /$ ehxA/saa & A & 11 & $\mathrm{C}$ & 1 \\
\hline & & & & & & $\mathrm{F}$ & 1 \\
\hline XXIX & AREXWX01.0011 & O103:NM & st $x_{1}$ & $\mathrm{D}$ & 13 & $\mathrm{C}$ & 2 \\
\hline $\mathrm{XXX}$ & AREZDX01.0024 & $\mathrm{O} 174: \mathrm{H} 21$ & $s t x_{2 \mathrm{c}(\mathrm{vh}-\mathrm{b})}$ & $\mathrm{C}$ & 12 & $\mathrm{~F}$ & 2 \\
\hline
\end{tabular}

${ }^{a} \mathrm{~F}$, feces; C, carcass.

participating abattoirs had the high quality and safety standards required by international markets.

The prevalence of non-O157 STEC in the fecal contents of cattle was on average $22.3 \%$ (95\% confidence interval, 19.6 to $25.3 \%$ ) upon entering the abattoirs. In a previous study of 200 bovines from Argentina, Meichtri et al. (22) found a 39\% prevalence of non-O157 STEC in feces. However, that survey considered only young steers, mostly sampled during the spring months. In the present study, bovines were selected on basis of the commercial operation of the exporting abattoirs. Therefore, most of the cattle were steers, mainly intended for meat cut exportation. Nonetheless, there was a significant number of cull cows, processed exclusively in one abattoir, and also young steers, calves, and heifers, mostly for the domestic market.

Some interesting tendencies were observed; cull cows showed a relatively higher STEC prevalence in feces (26.3\%), followed by calves $(23.4 \%)$, which are considered more susceptible to STEC infection (6). The high STEC prevalence in feces of cull cows is significant because of 

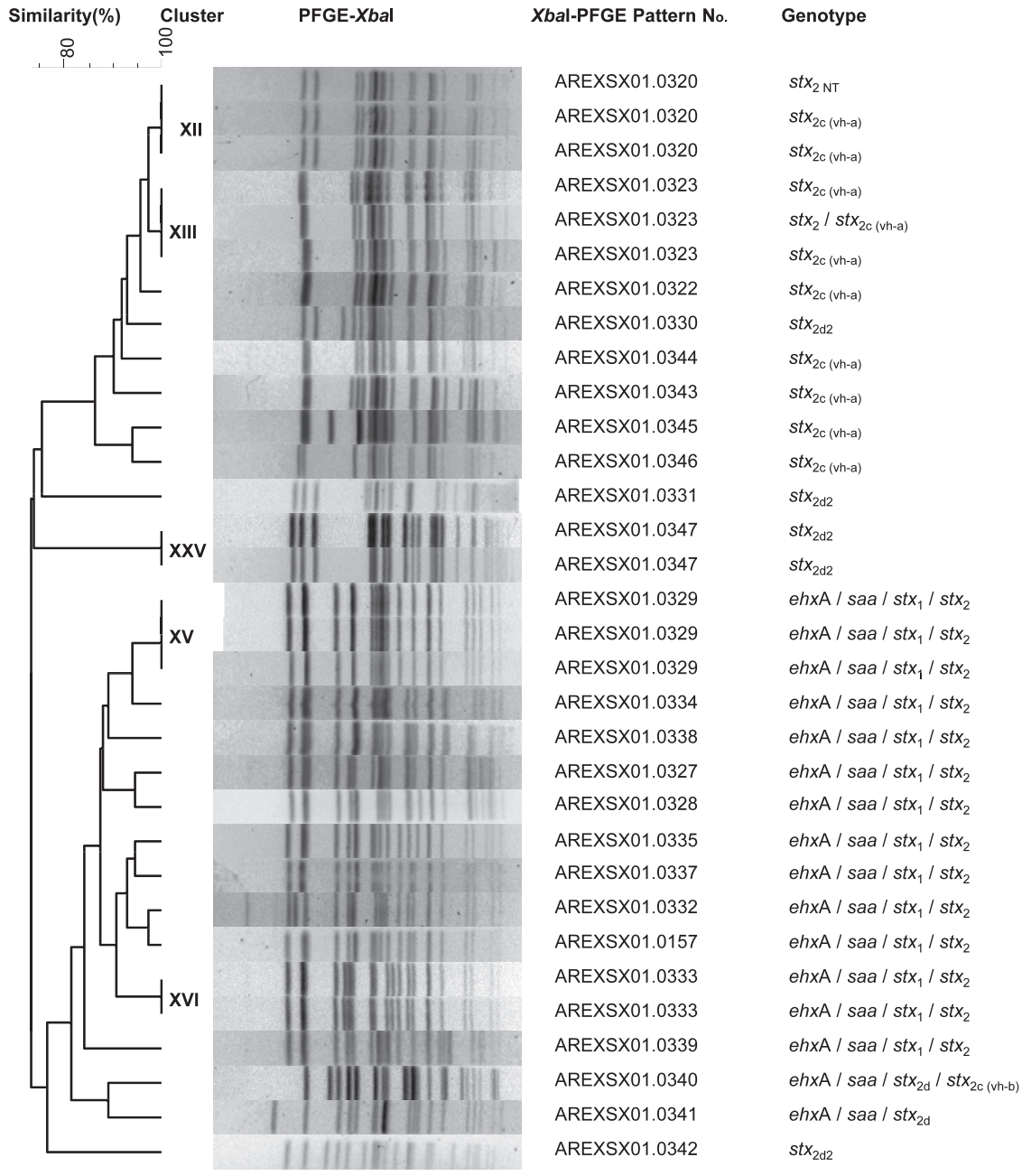

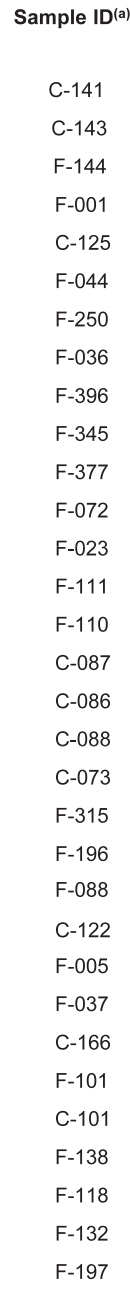

\begin{tabular}{l} 
Bovine Type \\
heifer \\
heifer \\
heifer \\
heifer \\
steer \\
young steer \\
steer \\
steer \\
cow \\
young steer \\
calf \\
steer \\
steer \\
steer \\
steer \\
young steer \\
young steer \\
young steer \\
steer \\
calf \\
steer \\
young steer \\
steer \\
steer \\
steer \\
cow \\
steer \\
steer \\
steer \\
cow \\
steer \\
steer \\
\hline
\end{tabular}

\begin{tabular}{|c|c|}
\hline Abattoir & Visit No \\
\hline G & 5 \\
\hline $\mathrm{G}$ & 5 \\
\hline $\mathrm{G}$ & 5 \\
\hline G & 1 \\
\hline B & 5 \\
\hline A & 1 \\
\hline$C$ & 11 \\
\hline $\mathrm{F}$ & 1 \\
\hline$D$ & 14 \\
\hline G & 12 \\
\hline G & 13 \\
\hline $\mathrm{F}$ & 3 \\
\hline $\mathrm{H}$ & 3 \\
\hline c & 6 \\
\hline C & 6 \\
\hline$D$ & 2 \\
\hline $\mathrm{D}$ & 2 \\
\hline $\mathrm{D}$ & 2 \\
\hline $\mathrm{F}$ & 3 \\
\hline$D$ & 10 \\
\hline $\mathrm{F}$ & 7 \\
\hline E & 4 \\
\hline B & 5 \\
\hline $\mathrm{H}$ & 1 \\
\hline C & 3 \\
\hline $\mathrm{H}$ & 8 \\
\hline B & 4 \\
\hline B & 4 \\
\hline C & 7 \\
\hline G & 4 \\
\hline$E$ & 5 \\
\hline $\mathrm{F}$ & 7 \\
\hline
\end{tabular}

FIGURE 2. Clonal relatedness between 32 STEC O178:H19 strains isolated from bovine carcass swabs and fecal contents.

their destination for ground beef. On average, the STEC prevalence was higher in summer and lower in the winter months, with the highest prevalence per group and season observed in calves in the spring (57\%), though this prevalence value must be considered an estimation because of the lower number of bovines sampled in this category.

The average prevalence of non-O157 STEC in bovine carcasses was $9.0 \%$ (95\% confidence interval, 7.2 to $11.1 \%$ ). This prevalence is comparable to values reported in decontaminated beef carcasses (1), though the abattoirs participating in this study did not apply any carcass decontamination process. Non-O157 STEC strains were detected in $32 \%$ of the carcass lots, mostly (63\%) in only one of the six carcasses analyzed. The highest prevalence, four to six contaminated carcasses, was observed in less than $10 \%$ of positive lots.

In $80 \%$ of the lots with positive carcasses, non-O157 STEC strains were isolated from bovine feces. By XbaIPFGE, clusters V, XIV, XVI, XXIV, and XXVIII showed clonal relatedness between strains isolated from carcasses and feces of the same animal, while clusters II, IX, XI, and XII demonstrated a relationship between carcass contamination and that observed in the feces of another bovine in the same lot. Thus, in $12.3 \%$ (9 of 73) of carcasses, there was evidence of contamination with identical non-O157 STEC strains within the lot.

Non-O157 STEC contamination of carcasses changed from lot to lot; however, on average in the abattoirs examined, two bovine carcasses were contaminated per five animals carrying non-O157 STEC in their feces. Further operations will modify this initial contamination, depending on specific production processes and hygiene conditions. Different surveys carried out in Argentina have established values of prevalence of non-O157 STEC in meat products as $28 \%$ in hamburgers $(25), 8.4 \%$ in frozen hamburgers (10), and $1 \%$ in precooked sausages (24).

In Argentina, around 30\% of postenteric HUS cases are caused by non-O157 STEC strains. Data collected at the National Reference Laboratory for HUS surveillance of Argentina showed that in a 5-year period (2004 to 2009), there were 1,066 STEC-associated infections reported, among which the prevalent non-O157 STEC O-groups were $\mathrm{O} 145(17.5 \%), \mathrm{O} 121(2.4 \%), \mathrm{O} 26(2.0 \%), \mathrm{O} 174$ (1.4\%), $\mathrm{O} 111(1.0 \%)$, and $\mathrm{O} 103(0.7 \%)$ (28). In the present study, 53.6\% (157 of 293) of non-O157 STEC isolates belonged to serotypes associated with human disease worldwide, including Argentina. Similarly, Meichtri et al. (22) reported a proportion of $51.2 \%$ of non-O157 STEC 
strains associated with disease in cattle of Argentina. Six serotypes (O178:H19, O8:H19, O130:H11, O113:H21, O103:[H2], and O174:H21) accounted for $41 \%$ of isolates. The second-most-prevalent serotype was $\mathrm{O} 8: \mathrm{H} 19$, at $8.4 \%$ in feces; this serotype was also prevalent $(12.8 \%)$ in the study performed by Meichtri et al. (22).

The non-O157 STEC strains isolated in this study could be sorted into the five seropathotype groups described by Karmali et al. (15). Non-O157 STEC strains wherein the $\mathrm{O}$ or $\mathrm{H}$ group could not be established (ONT and HR) were not allocated to any group (101 isolates). Fourteen (4.8\%) strains of seropathotype B were detected: O103:[H2] (10 strains) O145:NM (3 strains), and O111:NM (1 strain). In Argentina, O145:NM is the main non-O157 STEC serotype found in cases of human disease; three strains of this serotype were isolated from fecal samples $(0.36 \%$ prevalence) of two calves and one young steer during the spring and summer seasons. STEC O111:NM is one of the most common serotypes associated with HUS in Australia (6). In Argentina, it is responsible for $1 \%$ of the HUS cases reported, and in this study, it was recovered from a steer $(0.12 \%$ frequency in feces) during the summer season. STEC O103:[H2] strains were isolated from one carcass and nine fecal samples $(1.11 \%$ prevalence in feces) in four visits to the abattoirs. Interestingly, in one lot of cull cows sampled in the summer, six of six bovines were positive for STEC O103:[H2] in feces. Other serotypes from seropathotype B were not isolated, although previous surveys conducted in Argentina have recovered serotypes O26:H11 and O121:H19 from cattle feces (9, 22). Only one strain from seropathotype $\mathrm{B}$ was isolated from carcasses; however, this result may be an underestimation of the true prevalence of seropathotype B strains, as no specific methodology for detection of those serotypes was used in this survey.

In general, the serotypes included in seropathotype $\mathrm{C}$ are associated with sporadic diarrhea and HUS cases worldwide and in Argentina. One hundred twenty-seven (43.3\%) STEC strains of this seropathotype, belonging to serotypes O178:H19, O8:H19, O130:H11, O113:H21, O174:H21, O91:H21, O22:H8, O8:H16, O153:H25, O163:H19, and O165:NM, were isolated from feces and carcasses during this survey (Table 4). Strains of seropathotype $\mathrm{C}$ were present in $53.4 \%$ (39 of 73) of STEC-positive carcasses. According to Rivas et al. (28), O174 is the predominant non-O157 STEC serogroup isolated from foods in Argentina. Interestingly, strains of the 0174:H21 serotype were recovered from 11 samples (7 fecal and 4 carcass), representing $3.8 \%$ of the nonO157 STEC serotypes.

Isolates of serotypes O103:NM, O82:H8, O22:H16, O79:H19, O179:H8, O15:H27, and O116:H21 that occasionally produce a mild disease (seropathotype D) represented $5.5 \%$ of the isolates. Strains of this seropathotype were present in $9.6 \%$ (7 of 73) of the STEC-positive carcasses. Approximately $12 \%$ of non-O157 STEC strains isolated in this study have not been previously associated with human disease (seropathotype E).

The ability of STEC strains to produce bloody diarrhea and HUS in humans has been associated mainly with the expression of stx 2 gene variants, especially in combination with the eae gene. Similar to the results of other studies conducted in the bovine reservoir, most strains were st $x_{2}$ positive $(90.6 \%)$ alone or combined with $s t x_{1}$, while $s t x_{2}$ alone was prevalent $(28.3 \%)$. In a similar study conducted in Argentina, $s t x_{2}$ was detected in $19.8 \%$ of isolates (22). In the present study, the most frequent genotype detected was stx $1 /$ st $x_{2} /$ ehxA/saa.

Half $(49.5 \%)$ of the non-O157 STEC strains carried the saa gene, but only $22(7.5 \%)$ strains carried the eae gene, always in combination with $e h x A$. The genotypes of the eaepositive strains were as follows. st $x_{1} /$ eae/ehxA occurred in 12 strains of serotypes O103:[H2] (10 strains), O111:NM (1 strain), and ONT:NM (1 strain). The stx $x_{2} /$ eae/ehxA genotype was established in seven strains of serotypes O145:NM (3 strains), O139:H25 (1 strain), ONT:H7 (1 strain), and ONT:NM (2 strains). Two strains, of serotypes O165:NM and ONT:H19, harbored the $s t x_{2} /$ st $x_{2 \mathrm{c}(\mathrm{vh}-\mathrm{a})} /$ eae/eh $x A$ genotype. One strain, of serotype ONT:H28, carried the $s t x_{2 \mathrm{c}(\mathrm{vh}-\mathrm{b})} /$ eae/ehxA genotype. Thus, isolates characterized by a fully virulent genotype included the 14 strains of the group B seropathotype (O103:[H2], O145:NM, and O111:NM), 1 strain of seropathotype C (O165:NM), 1 strain of seropathotype $\mathrm{E}(\mathrm{O} 139: \mathrm{H} 25)$, and 6 strains from other serotypes (ONT:H7, ONT:H19, ONT:H28, and ONT:NM). Only $0.25 \%$ ( 2 of 811 ) of carcasses were contaminated with fully virulent non-O157 STEC strains; these strains were O103:[H2] stx 1 /eaelehxA and ONT:H7 stx $2 /$ eaelehxA.

When the XbaI-PFGE patterns were compared with those included in the Argentine PulseNet Database, the following matches were identified: one strain of serotype O178:H19, genotype $s t x_{1} / s_{2} / x_{2} / e h x A / s a a$, isolated from the carcass of a cow, possessed a pattern (AREXSX01.0157) identical to that of a strain (HUS 96/00) isolated from an HUS case in Argentina. Two other patterns were recognized in two strains previously isolated from a beef product (beef medallion) during routine sanitary inspections of food processors. Those patterns, AREXBX01.0015 and AREXPX01.0013, corresponded to strains in cluster XXIV (serotype O8:H19), and strains in cluster IX (serotype O113:H21), respectively.

The actual importance of non-0157 STEC as a foodborne pathogen is a matter of debate and research. Infection by some serotypes of non-O157 STEC has been demonstrated to occur through a variety of foods. However, in comparison to the data for STEC O157, there are fewer data to link non-O157 STEC infection to foods, particularly to meat products. Likewise, in a case-control study conducted in Argentina, Rivas et al. (29) found that meat consumption was highly correlated to human illnesses caused by STEC O157 but not to those caused by non-O157 STEC strains.

The information gathered in the present study can aid better estimation of the risk from non-0157 STEC in the beef industry of Argentina. In this survey, it was found that non-O157 STEC strains with a fully virulent genotype were present in a relatively low proportion $(0.25 \%)$ of carcasses; however, $4.8 \%$ of bovine carcasses were contaminated with 
non-O157 STEC strains from seropathotype C, which are potentially capable of producing sporadic human disease.

\section{ACKNOWLEDGMENTS}

This project was financed by public funds (research project AETA3692) of the Instituto Nacional de Tecnología Agropecuaria de Argentina (National Institute for Agricultural Technology, INTA). We acknowledge the Instituto de Promoción de la Carne Vacuna Argentina (IPCVA; Argentine Beef Promotion Institute) for their logistic support that made this work possible. The technical assistance of Gerónimo Ortigoza is acknowledged.

\section{REFERENCES}

1. Arthur, T. M., G. A. Barkocy-Gallagher, M. Rivera-Betancourt, and M. Koohamaraie. 2002. Prevalence and characterization of non-O157 Shiga-toxin producing Escherichia coli on carcasses in commercial beef cattle plants. J. Food Prot. 68:4847-4852.

2. Beutin, L., M. A. Montenegro, I. Ørskov, J. Prada, S. Zimmermann, and R. Stephan. 1989. Close association of verotoxin (Shiga-like toxin) production with enterohemolysin production in strains of Escherichia coli. J. Clin. Microbiol. 27:2559-2564.

3. Boop, C. 2008. Non-O157 Shiga-toxin producing Escherichia coli isolation and detection challenges. Centers for Disease Control and Prevention, Atlanta. Available at: www.fsis.usda.gov/PPT/ Non-0157_STEC_Bopp.ppt. Accessed 4 March 2011.

4. Centers for Disease Control and Prevention. 1995. Outbreak of acute gastroenteritis attributable to Escherichia coli serotype O104:H21, Helena, Montana, 1994. Morb. Mortal. Wkly. Rep. 44:501-503.

5. Centers for Disease Control and Prevention. 1995. Community outbreak of hemolytic uremic syndrome attributable to Escherichia coli O111:NM, South Australia, 1995. Morb. Mortal. Wkly. Rep. 44: 550-551, 557-558.

6. Desmarchelier, P. M. 1997. Enterohemorrhagic Escherichia coli-the Australian perspective. J. Food Prot. 60:1447-1450.

7. Eblen, D. R. 2007. Public health importance of non-O157 Shiga toxin-producing Escherichia coli in the US food supply. U.S. Department of Agriculture, Food Safety and Inspection Service. Available at: http://www.fsis.usda.gov/PDF/STEC_101207.pdf. Accessed 4 March 2011.

8. Ewing, W. H. 1986. Edwards and Ewing's identification of Enterobacteriaceae, 4th ed. Elsevier, New York.

9. Gioffré, A., L. Meichtri, E. Miliwebsky, A. Baschkier, G. Chillemi, M. I. Romano, S. Sosa Estani, A. Cataldi, R. Rodríguez, and M. Rivas. 2002. Detection of Shiga toxin-producing Escherichia coli by PCR in cattle in Argentina. Evaluation of two procedures. Vet. Microbiol. 87:301-313.

10. Gómez, D., E. Miliwebsky, C. Fernandez Pascua, A. Baschkier, E. Manfredi, M. Zotta, F. Nario, A. Piquín, M. Sanz, A. Etcheverría, N. Padola, A. Parma, and M. Rivas. 2002. Aislamiento y characterization de Escherichia coli productor de toxina Shiga en hamburguesas supercongeladas y quesos de pasta blanda. Rev. Arg. Microbiol. 34: 66-71.

11. Johnson, K. E., C. M. Thorpe, and C. L. Sears. 2006. The emerging clinical importance of non-O157 Shiga toxin-producing Escherichia coli. Clin. Infect. Dis. 43:1587-1595.

12. Karch, H., H. Bohm, H. Schmidt, F. Gunzer, S. Aleksic, and J. Heesemann. 1993. Clonal structure and pathogenicity of Shiga-like toxin-producing, sorbitol-fermenting Escherichia coli O157:H7. J. Clin. Microbiol. 31:1200-1205.

13. Karmali, M. A., M. Mascareñas, S. Shen, K. Ziebell, S. Johnson, R. Reid-Smith, J. Isaac-Renton, C. Clark, K. Rahn, and J. B. Kaper. 2003. Association of genomic O island 122 Escherichia coli EDL 933 with verotoxin-producing Escherichia coli seropathotypes that are linked to epidemic and/or serious disease. J. Clin. Microbiol. 41: 4930-4940.

14. Karmali, M. A., M. Petric, C. Lim, R. Cheung, and G. S. Arbus. 1985. Sensitive method for detecting low numbers of verotoxinproducing Escherichia coli in mixed cultures by use of colony sweeps and polymyxin extraction of verotoxin. J. Clin. Microbiol. 22:614619.

15. Karmali, M. A., B. T. Steele, M. Petric, and C. Lim. 1983. Sporadic cases of haemolytic-uraemic syndrome associated with faecal cytotoxin and cytotoxin-producing Escherichia coli in stools. Lancet i:619-620.

16. Leotta, G. A. 2006. Validación de una técnica de reacción en cadena de la polimerasa (PCR) para la detección de Escherichia coli productor de toxina Shiga en alimentos cárnicos. Tesis de Maestría en Microbiología Molecular. ANLIS "Dr. Carlos G. Malbrán” y Universidad Nacional de San Martín, Argentina.

17. Leotta, G. A., I. Chinen, S. Epszteyn, E. Miliwebsky, I. C. Melamed, M. Motter, M. Ferrer, E. Marey, and M. Rivas. 2005. Validación de una técnica de PCR múltiple para la detección de Escherichia coli productor de toxina Shiga. Rev. Arg. Microbiol. 37:1-10.

18. Machado, J., F. Grimont, and P. A. Grimont. 2000. Identification of Escherichia coli flagellar types by restriction of the amplified fliC gene. Res. Microbiol. 151:535-546.

19. Masana, M. O., G. A. Leotta, L. L. Del Castillo, B. A. D'Astek, P. M. Palladino, L. Galli, E. Vilacoba, C. Carbonari, H. R. Rodríguez, and M. Rivas. 2010. Prevalence, characterization, and genotypic analysis of Escherichia coli 0157:H7/NM from selected beef exporting abattoirs of Argentina. J. Food Prot. 73:649-656.

20. Mathusa, E. C., Y. Chen, E. Enache, and L. Hontz. 2010. Non-O157 Shiga toxin-producing Escherichia coli in foods. J. Food Prot. 73: 1721-1736.

21. McCarthy, T. A., N. L. Barrett, J. L. Hadler, B. Salsbury, R. T. Howard, D. W. Dingman, C. D. Brinkman, W. F. Bibb, and M. L. Carter. 2001. Hemolytic-uremic syndrome and Escherichia coli $\mathrm{O} 121$ at a lake in Connecticut, 1999. Pediatrics 108:59-65.

22. Meichtri, L. H., E. Miliwebsky, A. Gioffré, I. Chinen, A. Baschkier, G. Chillemi, B. E. C. Guth, M. O. Masana, A. Cataldi, H. R. Rodríguez, and M. Rivas. 2004. Shiga toxin-producing Escherichia coli in healthy young beef steers from Argentina: prevalence and virulence properties. Int. J. Food Microbiol. 96:189-198.

23. Monday, S. R., A. Beisaw, and P. C. H. Feng. 2007. Identification of Shiga toxigenic Escherichia coli seropathotypes A and B by multiplex PCR. Mol. Cell. Probes 21:308-311.

24. Oteiza, J. M., I. Chinen, E. Miliwebsky, and M. Rivas. 2006. Isolation and characterization of Shiga toxin-producing Escherichia coli from precooked sausages (Morcillas). Food Microbiol. 23:283-288.

25. Parma, A. E., M. E. Sanz, J. E. Blanco, J. Blanco, M. R. Viñas, M. Blanco, N. L. Padola, and A. I. Etcheverría. 2000. Virulence genotypes and serotypes of verotoxigenic Escherichia coli isolated from cattle and foods in Argentina. Eur. J. Epidemiol. 16:757-762.

26. Pièrard, D., G. Muyldermans, L. Moriau, D. Stevens, and S. Lauwers. 1998. Identification of new verocytotoxin type 2 variant B-subunit genes in human and animal Escherichia coli isolates. J. Clin. Microbiol. 36:3317-3322.

27. Ribot, E. M., M. A. Fair, R. Gautom, D. N. Cameron, S. B. Hunter, B. Swaminathan, and T. J. Barrett. 2006. Standardization of pulsedfield gel electrophoresis protocols for the subtyping of Escherichia coli O157:H7, Salmonella, and Shigella for PulseNet. Foodborne Pathog. Dis. 3:59-67.

28. Rivas, M., I. Chinen, E. Miliwebsky, L. Galli, H. A. Repetto, and M. Masana. 2011. Epidemiology of Argentinean Shiga toxin-producing Escherichia coli, p. 109-132. In S. T. Walk and P. C. H. Feng (ed.), Population genetics of bacteria: a tribute to Thomas S. Whittam. ASM Press, Washington, DC.

29. Rivas, M., S. Sosa-Estani, J. Rangel, M. G. Caletti, P. Vallés, C. D. Roldán, L. Balbi, M. C. Marsano de Mollar, D. Amoedo, E. Miliwebsky, I. Chinen, R. M. Hoekstra, P. Mead, and P. M. Griffin. 2008. Sporadic Shiga toxin-producing Escherichia coli infections in children, Argentina. Emerg. Infect. Dis. 14:763-771.

30. Schmidt, H., L. Beutin, and H. Karch. 1995. Molecular analysis of the plasmid-encoded hemolysin of Escherichia coli O157:H7 strain EDL 933. Infect. Immun. 63:1055-1061.

31. Spizzirri, F. D., R. C. Rahman, N. Bibiloni, J. D. Ruscasso, and O. R. Amoreo. 1997. Childhood hemolytic uremic syndrome in Argentina: long term follow-up and prognostic features. Pediatr. Nephrol. 11: $156-160$. 
32. Tyler, S. D., W. M. Johnson, H. Lior, G. Wang, and K. R. Rozee. 1991. Identification of verotoxin type 2 variant B subunit genes in Escherichia coli by the polymerase chain reaction and restriction fragment length polymorphism analysis. J. Clin. Microbiol. 29:13391343.

33. U.S. Department of Agriculture, Food Safety and Inspection Service. 2005. Incident Investigation Team methodology for Escherichia coli
(E. coli) $\mathrm{O} 157: \mathrm{H} 7$ in beef slaughter establishments. Available at: www.fsis.usda.gov/PDF/IIT_Methodology_for_Ecoli.pdf. Accessed 4 March 2011

34. Zhang, W., M. Bielaszewska, K. Thorsten, and H. Karch. 2002. Identification, characterization, and distribution of a Shiga toxin 1 gene variant $\left(s t x_{1 \mathrm{c}}\right)$ in Escherichia coli strains isolated from humans. J. Clin. Microbiol. 40:1441-1446. 